\title{
PHYSICAL CONFLICT ANALYSIS IN THE NOVEL "INTO THIN AIR" BY JON KRAKAUER
}

\author{
Chandra Ivan ${ }^{1}$ \\ Sekolah Tinggi Bahasa Asing - IEC Jakarta \\ chandraivan130694@gmail.com \\ Agita Violy \\ Sekolah Tinggi Bahasa Asing - IEC Jakarta \\ agitavioly@gmail.com
}

Ivan, C. and Violy, A. (2021). Physical Conflict Analysis in the Novel "Into Thin Air" By Jon Krakauer. Journal of English Language and literature, 6(2), 31-40. doi: 10.37110/jell.v6i2.122

Received: 12-07-2021

Accepted: 21-08-2021

Published:03-09-2021

\begin{abstract}
This research aims to enlarge knowledge and understanding the element of literature, especially in conflict element. It is very important to know about conflict in literature because the readers can understand to response every condition through representation conflict in this novel. The writer focuses on conflict rising up from the beginning to the end of the story. There are so many people in the groups that want to climb Everest. And of course, in an expedition, especially in a dangerous mountain like Everest has so many conflicts. This research is descriptive qualitative research. This thesis uses physical conflict analysis and also applies psychological aspect to analyze the main characters' characteristics when struggle a force of nature such as the rogue storm that caused disaster. The story reminds the readers of a journey of life. It reminds us that everybody do not be arrogance and must ready to face everything that will happen in the future. It also remind us to being trust and loyalty among teammate.
\end{abstract}

Keywords: Novel, Conflict, Characters, Physical Conflict Analysis

\section{INTRODUCTION}

Literature means writing valued as work of art. It also refers to the composition that tells stories, drama, situations, expressions, and emotions. Literature is part ofhuman's life. Literature is the result of happiness, sadness, likeness, etc. The authorusually makes their life, their love, emotion, and tragedy becomes some literature.It also gives explanation that literature cannot be separated from life because literature is one of the bridges to make someone communicate with others about life's condition by his works.

In the literature itself, there are some genres of literary work such as, poetry, drama, and prose. Prose are still limited into three such as short story, novelette and novel. Novel belongs to prose. Novels as one of literary works are present a world which consist of ideal models in a life, imaginative life built based on the events, plot, actors, point of view, places, etc, in which are narrative prose.
Many kinds of story in a novel such as religion, family, social, education, friendship, culture, war, love and others. It also talks about human activities and describes what happened in surrounding.

Conflict must happen in human life. Conflict does not always have negative impact. With the conflict, people can get the best solution in every problem that happens in human life.

Physical conflict is a type of external conflict that occurs in the story when individual character struggle against other external force. The physical conflict or elemental conflict that occurs within the main character between man and nature.

Related to the explanation above, the important research objectives are designed to find the answer of the research questions which are the major characters, the physical conflict and the moral value. The main objective of this research are: (1) to find out the major characters and

${ }^{1}$ Corresponding Author 
their goals in the novel Into Thin Air (2) to find out the physical conflict (3) to find out the moral value

\section{REVIEW OF LITERATURE}

\section{Novel}

Kennedy states that a novel is a book-length story in prose, whose author tries to create the sense while we read, we experience actual life. Bennett and Royle argue that literature is the kind of writing which most persistently and most provocatively engages with the uncanny aspects of experience, thought and feeling. Taylor also defines that a novel is a normally a prose work with a quite length complexity which attempts to reflect an express something of the quality of value of human experience.

It can be concluded that novel is one of literary works are present a world which consist of ideal models in a life or it describes the characters and phenomena from the real human life

\section{Genres of Novel}

There are two genres of novel such as fiction and non-fiction. Fiction is one of literary works in which the imagination of the author is expressed. According to Sudjiman, fiction is the narrative that has character, acting, and the flow generated by the imagination or the imagination, in a variety of prose. He explained that the fictional composition is the result of an author's imagination that contains elements such as character, plot, and others. The elements are mutually sustainable so that theoccurrence of a story.

The non fiction novel is the form of data and facts. So there is no element of the author's imagination. Aceng Hasani provides limitation that a novel can be classified in to non fiction if there are data that can be verified inside. Besides, non fiction novel have also been prepared bythe facts that actually occurred in the field without any element of imaginationof the author.

\section{Elements of Novel}

Intrinsic element of novel is the important components that must be exist into novel to create or built a good novel and deserve to be read by the people.

\section{(a) Plot}

Plot is the events that makes up the story, particularly as it relates to one another in a pattern, in a sequence, through causeand effect, how the reader views the story, or by coincidence. Lukens says that plot is more than sequence of actions or conflict. Plot divides into five parts such as exposition, rising action, climax, falling action, and resolution.

\section{(b) Character}

The important of character will determine the developed and understood by readersof the fully characters in the novel. Abrams defines character as an actor or actrees who has role in story or presented in dramatic or narrative work, who is interpreted by the readers as being edowed with moral and disponsitional qualities that are expressed in what they say (dialogue) and what they do (action). Stanford defines that the protagonist is the major character with whom we generally symphatize, while the antagonist is the character with whom the protagonist is in conflict. According to Dietsch, there are two types of characters; they are main or major character and minor character.

\section{(c) Theme}

Theme is the idea that holds the story together, such as a comment about society, human nature, or the human condition. It is the main idea or central meaning of piece of writing. Kennedy says that the theme of a story is whatever general idea or insight the entire story reveals. Theme reflects a universal belief about human life or "the human condition"- those experiences that are basic to the human race, regardless of color, class, or century. Lukens divides the theme into two types; they are explicit theme and implicit theme. Explicit theme sometimes the writer states theme openly and clearly. Explicit themes are easily understood. In contrast, implicit theme is as important and almost as apparent.

\section{(d) Point of View}

Point of view is an integral tool of description inthe author's hands to portray personal emotions or characters' feelings about an experience or situation. This element is very crucial in every prose especially in novel. In common way this part is called narrator who has function to link every story to be a package of novel.

\section{(e) Setting}

Setting is very important in a story. It is what gives background to the story. Itgives the reader information where the story is taking place. Mario Klarer explains that setting is describing where and when do the events take place. Setting will be able to answer the question about where and when of the eventshappen in story. It explains place and time of the story. 
Setting can be divided become three majors such as setting of place, setting of time, and setting of society.

\section{Conflict}

According to Lukens, a conflict is a struggle against opposing forces, occurs when the protagonist against an antagonist, or opposing force. Conflict must happen in human life. Conflict does not always have negative impact. With the conflict, people can get the best solution in every problem that happens in human life. While Gordon and Kuehner say that conflict is an internal or external struggle between main character and an opposing force. Conflict happens because of some different reasons. The differences can be physics, knowledge, customs, belief, etc. Wellek and Warren state that the conflict is something dramatic, inexpediency perception between two people in a story. Conflict occurs because of there is no agreement reached toward each desires of individuals. This case usually happenedin the real life in which the people try to avoid it. However, in a literary work, conflict is very important to support the content of the story. The reader certainly will not be interested if there is no conflict happened in a story.

\section{Types of Conflict}

The event in a literary work will be related to the conflict. Nurgiyantoro explains that conflict categorized into two kinds, internal conflict and external conflict.

\section{(a) Internal Conflict}

Internal conflict is the trouble which occurs inside the character itself and usually there are anger and rages in mind without influence and is caused by outsideelement of the character. This conflict can describe that the character tries to convince himself to decide something. It is commonly said "Man versus Self" or acharacter against himself or herself.

\section{(b) External Conflict}

Unlike internal conflict, external conflict deals with the problems of the world. The story's characters will struggle against the situation of external conflict, they may even suffer internal conflict resulting from the issues of external conflict,but this not as simple as internal conflict. External conflict occurs when character are involved in the world's misery, such as community, nature, government and other characters are all examples of external conflict. Sayuti divides conflict into three kinds:

\section{(a) Psychological Conflict}

The psychological conflict or internal conflict is man struggling against himself, his conscience, his guilt, or simply trying to decide that he/she is going to do. In such a story we may see a honest but poor bank employee fighting the temptation to steal from his bank, a woman struggling with the sequences of a lie she's told, or an unwed pregnant girl trying to decide whether to have an abortion, place her child up for adoption, or raise him alone. According to Sayuti, Psychological conflict is showing how the actor's effort fightsher/himself in order to solve and determine what will the actor do next.

The psychological conflicts of the main character consist of; affection, anxiety, jealous, anger, disagree, sadness, love, unlike, hoping, arrogant, pity, and happiness.

\section{(b) Social Conflict}

Social conflict is a conflict the struggle is of one person against another. One character against another as known as man versus man is the most fundamental type of external conflict. This form of external conflict happens when a character struggles against another character. Woods says that a variation of this conflict sets on character against a few others. It is common type that happens in story of novel. These struggles include moral, religious, social or paradigm differences, verbal or physical conflicts.

Social conflict also happen between an actor and the people in a society where she or he lives. This conflict appears because of actor's attitude to the social environment concerning the problems occurring in society.

\section{(c) Physical Conflict}

Physical conflict is a type of external conflict that occurs in the story when individual character struggle against other external force. It is one of conflict in which the actor cannot make the best use of fifth of nature around him/her. The disharmony happened to human toward the nature will turn the conflict up. This plot gives some adventure experience of novel and the story tells smartly and conquers emotion to take into different experiences. Physical conflict or man versus nature conflicts occur when a character, or characters, find themselves at odds with forces of nature.

In psychoanalysis theory, Freud states that in a human personality, there are three important systems: Ego, Id and Superego. These three systems become a harmonic structure. 
(a) Ego

Ego is personality element that has been responsible to handle the reality. The example is when Ego has been threatened; angry is the best way to express Ego. Angry is a form of Ego or called being selfish. Ego is the element of psyche that has responsibly to handle a realistic. It develops from id then make sure that id desire can be realized and accepted into realistic world. Ego is also called as a way to release a stress of life that cannot be created by id in mind and ego try to give pictures into reality.

(b) Id

Id is a gift from god and it has been brought since born with purpose to make civilization in the world. Defensing to the world in generalmeaning is one kind of Id. Defensing world such as how to eat when starvingor how to drink when thirsty. Id can be called instinct and that form is more familiar in common speaking. Id in human produces to focus into physic needs.

\section{(c) Superego}

Superego is the third personality element of psyche that distinguishes human and animal. Superego has a responsible to control id and ego then human can select the best option and thinking what the effect of activity that will be done. Superego is formed by social, family, religion or nation. Superego development can receive tradition from family and then builds a shield to protect or control Ego and Id to the right path.

\section{METHOD}

In terms of analyzing the formulation of the problems in the novel Into Thin Air, qualitative method is used in this research. Burhan defines that qualitative study focuses on describing and analyzing a phenomenon, social activity, perception, belief, individual and thought.

This technique supports the research to achieve the objective which clearly describes about physical conflict Analysis in the novel Into Thin Air, finds the major character and finds the moral value.

This research the collection of data will presented in several ways as follows: a) reading, b) finding c) selecting, d) analyzing, e) concluding.

The steps of data processing and data analysis covered several intentions as follows: a) taking data, b) determining, c) extracting

\section{FINDINGS AND DISCUSSION}

Finding

Character of The Novel Into Thin Air by Jon Krakauer.

Into Thin Air Novel has many character that can be described, those are:

\section{a) Jon Krakauer}

Despite his soft-and-chewy journalistic exterior, Krakauer is a wild manat heart. He was a die-hard mountaineer during his twenties and actually achieved some seriously impressive ascents, though he never reached altitudesas high as he does on Everest.

\section{b) Rob Hall}

Rob Hall is faithful person. As the leader of the most prominentcommercial guiding firm on the mountain, Hall knows a thing or two about the changing landscape of Everest, with more people than ever flocking to the mountain who have less and less experience.

\section{c) Andy Harris}

Andy Harris is loyal and trusty guide. He tried to save Rob Hall and Doug Hansen when they stucked in the South of Summit. Andy Harris's death hits Jon Krakauer the hardest.

\section{d) Sandy Pittman}

Sandy Pittman is a selfish climber. She is a wealthy socialite and tabloidfixture - in fact, she's married to MTV co-founder Robert Pittman.

\section{e) Beck Weathers}

Beck Weathers is patient, calm, and love his family. Weathers somehow survives the brutal storm.

\section{f) Ang Dorje Sherpa}

Ang Dorje is Rob Hall's number one Sherpa because he is loyal, heroic, and strong.

\section{g) Mike Groom}

An Australian guide with Adventure Consultants.

\section{h) Doug Hansen}

A client with Adventure Consultants.

\section{i) Yasuko Namba}

Namba is a Japanese woman whose attempt to climb Everest gained much notoriety in Japan. the brief glimpses we do get reveal a focused, determined, and courageous woman.

j) Stuart Hutchinson

A Canadian client with Adventure Consultants.

k) Scott Fischer 
The head guide of the Mountain Madness expedition group.

\section{l) Anatoli Boukreev}

A guide with Scott Fischer's group, Boukreev is a world-respected climber who had previously summated Everest with no supplemental oxygen.

\section{m) Neal Beidleman}

Another excellent climber, Beidleman is a guide with Fischer's service.

\section{n) Lopsang Jangbu Sherpa}

Fischer's main Sherpa. Lopsang is exceedingly loyal to Fischer, and helps secure ropes and haul supplies all the way up the mountain.

\section{o) Tim Madsen}

Madsen is a client with Scott Fischer's guide service.

\section{p) Ian Woodall}

The leader of the South African expedition.

\section{q) Makalu Gau}

The leader of the Taiwanese climbing group.

\section{Discussion}

\section{Major Characters and Their Goals}

Abrams defines character as an actor or actrees who has role in story orpresented in dramatic or narrative work, who is interpreted by the readers as being edowed with moral and disponsitional qualities that are expressed in what they say (dialogue) and what they do (action).

When the author climb Everest, there are two groups expedition; Adventure Consultants and Mountain Madness. There are so many people in the groups that want to climb Everest. And of course, in an expedition,especially on a dangerous mountain causes so many conflicts of the character'swhen struggle a force of nature such as the rogue storm that caused disaster.

Here is the major characters in the novel Into Thin Air and what their goals when climb Everest:

\section{a) Jon Krakauer}

Krakauer has a multi-faceted role in this book. First andforemost, he is a character, the narrator of the story he tells. Secondly, he is the author of this book. Third, he is a mountain climber. He is protagonist and has static character. From the beginning of the story until the conflict rising up, Krakauer still be submissive climber who strict with the rule.

Krakauer has always dreamed of reaching the top of Mount Everest. As following this quotations
p-ISSN 2540-8216, e-ISSN 2654-3745

https://journal.stibaiec-jakarta/ojs/index.php/jell

"The editors simply wanted [him] to remain in BaseCamp and report the story."

Throughout the text, Krakauer attempts to figure out exactly what went wrong and what happened to him. He does extensive research and painstakingly traces the actions of every climber on the mountain. He theorizes about the breakdowns of the expedition, and attributes the disaster to a series of small mistakes. He includes himself, and explicitlyblames himself for at least one person's death. The experience affects him profoundly, and in addition to telling the story, the book focuses onhow Krakauer is forever changed as a result of what happened.

\section{b) Rob Hall}

Hall is Krakauer's guide, and leads them up the mountain impressively until the summit attempt. Hall has begun climbing in the Himalayas since nineteen years old, and successfully climbed the highest mountain in each of the seven continents within a period of seven months. After that feat, Hall decides that his future is in guiding, and brings a record number of clients to the summit of Everest. He is protagonist character in this novel. All of the clients like and respect Hall, and during the ascent he comes to the assistance of a number of climbers. Hall, though essential to everyone during the climb, does notadhere to his own turnaround time for the summit.

As the leader of the most prominent commercial guiding firm onthe mountain, he has static character. Hall knows a thing or two about the changing landscape of Everest, with more people than ever flocking to the mountain who have less and less experience. He even directly states this following quotation:

"with so many incompetent people on the mountain, it's pretty unlikely that they'll get through this season without something bad happening up high."

\section{c) Andy Harris}

Harris is one of the more altruistic guides on the expedition. Heis protagonist and has static character. He comes to the assistance of anyone and everyone without hesitation, and eventually that same sense of loyalty turns out to be his downfall.

One of Krakauer's biggest mistakes in the experience of writingthe book is misinterpreting what happened to Harris. Krakauer, saw Harris on the mountain and pointed him toward camp. Later, Krakauerconcluded that Harris had fallen off the mountain, but during a conversation with another 


\section{Chandra Ivan and Agita Violy}

Physical Conflict Analysis in the Novel "Into Thin Air" by Jon Krakauer

climber learns that it was not Harris he saw that night.

Harris's death is one of the single biggest tragedies to unfold during the expedition. Harris and his girlfriend had just begun buildinga house, but he couldn't resist the lure of the mountain. Always among the first to volunteer to do work or assist clients, Harris is one of the people Krakauer trusts throughout. Krakauer sees his younger self in Harris, as this following quotation:

"both men are very similar in terms of physical ability and technical expertise and share an equally fiery passion for mountaineering."

Harris hasn't been to Everest before, either. Despite their friendship, there remains a notable distinction between the two men: Harris is the guide and Krakauer is the client.

\section{d) Sandy Pittman}

Pittman is not one of the principal characters in terms of plot, but in terms of theme she has one of the most important roles. Pittman is heavily involved in the media, and goes along the expedition to dispatch pictures and information to $\mathrm{NBC}$ for broadcast on their website. She does not charge $\$ 65,000$ a head, but she represents a whole different kind of commercialism on the mountain. Because of work likePittman's, the entire world can see the fate of a climbing expedition.

Pittman is antagonist character. Pittman's presence causes complications. She requires the usage of a number of heavy pieces of equipment, which the Sherpas drag up the mountain for her. Lopsang Sherpa short-ropes her up one face of the mountain, exhausting himselfin the process. She and Krakauer make other climbers nervous, because they record and document the events on the mountain. After the expedition, she is met with lots of negative press and blame surrounding the disaster.

\section{e) Beck Weathers}

As a protagonist and has dynamic character, Weathers grows asthe novel progresses. Weathers is a doctor who has recently become obsessed with climbing, and initially, Krakauer does not think much of him. Throughout the climb, Weathers exhibits more and more character.One of the more gut-wrenching aspects of the story is Weathers' blindness that sets in the higher he climbs. Weathers persuades Hall to let him attempt the summit, and promises that if he cannot sit he will wait for the next guide. True to his word, Weathers sits and waits for hours, until Krakauer eventually stumbles upon him. After waiting hours for a guide, Weathers finally gets help down the mountain and joins the group that gets lost. During the rescue attempt, Boukreev leaves Weathers for dead. In a series of astounding feats of strength and spirit, Weathers stays alive. After being written off he eventually finds camp, ill and frostbitten. At camp, he is stripped of his sleeping bags ina fierce storm but lasts through the night. He also survives being broughtdown the mountain, finally seeing doctors at Base Camp who call his frostbite the worst they've ever seen.

All through the book Krakauer talks about the undying spirit of some climbers. Some climbers are driven to the point of being dangerous. Weathers is not as much driven as he is tough. $\mathrm{He}$ exemplifies the determination, strength and bravery. Though only a client, he is a one of a kind hero on the expedition.

\section{Physical Conflict Analysis}

In many ways, conflict powers the plot of a story, novel or screenplay. Narratives move forward due to the tension and suspense created by conflict, and most narratives have at least one central conflict and one or more ancillaryconflicts. Welldeveloped characters will often experience a conflict in a storyin a variety of ways, struggling with both internal and external challenges and forces. Even though four primary types of conflict can be identified, these conflicts will often overlap and blend in any given narrative.

Christine says that physical conflict is a type of external conflict that occurs in a story when individual characters struggle against other external forces. A character may struggle against other characters, animals or even natural forces. Physical conflict may manifest itself as problems with physical shelter or safety, or it may be reflected through fights between friends, family members or lovers.

Physical conflict occurs, as well, when characters strugglewith machines and technology, such as aliens or robots, or under natural disasters, such as hurricanes and earthquakes. The focusses will be explain here mman vs nature, the climber against the rogue storm.

Krakauer begins his adventure at base camp and over a period of a fewmonths works his way up along with his team to advanced base camp, and thena series of four camps that ultimately wind their way to the summit. Along theway, we learn how difficult it is just to breath - oxygen levels are $50 \%$ of normal at base camp, and only about $33 \%$ at the top. This challenge alone requires a 
completely different mind set to surviving the simplest of tasks, andalso means bottled oxygen is a necessity for all but the most strident climber. No matter how physically strong or mentally prepared, a climber can face manypotentially fatal outcomes including expansion of the brain, increased heart attack risk, and hallucinations that can lead to a variety of altitude sicknesses. At best, depleted oxygen results in the motor skills of a small child, and a needfor the body to begin to consume itself resulting in severe weight loss and potential starvation.

Krakauer, a strong climber himself, miraculously finds his way back to base camp amid much confusion, mistaken identities, and swirling winds that limit visibility to virtually zero. Compound this with temperatures below 40, and it's easy to understand how a sunny Everest peak can almost instantly transform into a death trap.

This is the step how the conflict rise up from the beginning to the end of story:

\section{a) They missed the schedule}

Schedule or itinerary is the most important thing when climb a mountain. This schedule allows plenty of time for upcoming illnesses and rest in the valley whilst climbing slowly. In addition, it provides for 2-3 summit attempts. It requires that the climber can reach BaseCamp early and leave late. It also requires the Icefall and other fixed rope preparations to be done in time.

As a way to minimize danger, Hall typically relies on fixed ropelines through the Death Zone. But this time there are no ropes are in place. Hall and Fischer decide to send two Sherpas each ahead of the rest of the climbers to take care of the ropes. However, the night beforethe summit attempt, no Sherpas left to fasten the ropes. No one is precisely sure why these plans fell through - perhaps high winds were a factor.

Ang Dorje, Hall's Sherpa, reveals that during a vision he had atBase Camp, he saw ghosts. Dorje plans on fixing the ropes, but becauseLopsang is late, they don't finish in time. The lack of ropes slows the climbers and causes a traffic jam at around 28,000 feet. The slow pace worries Hall, who is not sure they will be able to reach the summit by the turn around time.

There is some dispute about the turn around time-Hall says heis trying to decide between 1:00 pm and 2:00 pm, but never announceshis decision. Knowing that there is no way they would reach the summitby either of those times, climbers Taske and Hutchinson turn back. b) There is no oxygen and ropes in Hillary Step

Krakauer reflects on how difficult it would be to turn around thatclose to the top, after having endured all the misery to get that far and after paying sums of around $\$ 70,000$. He also thinks about the fact that the climbers who continue climbing despite safety, logic and ill health are dangerous, which poses a huge dilemma for Everest climbers.

As they approach the Hillary Step, the infamous vertical ridge, Krakauer notices that Boukreev is not carrying any additional oxygen or a backpack. It is the first time he has seen a guide elect not to carry gas or any other equipment. Boukreev says that he began that morning with oxygen and his backpack, but tossed them so as not to take up toomuch energy. Krakauer and two of Hall's Sherpas wait just below the Hillary Step, and when asked if they are going to fasten the ropes, Hall'sSherpas say no, presumably because no other Sherpas are there to help. Beidleman, Andy Harris and Boukreev finally decide to install the ropesthemselves, but by then there is a line of people waiting.

\section{c) The climbers get mountain sickness}

In this story it is safe to say that the biggest conflict is man vs. nature. Jon Krakauer was originally sent up there to report commercialism on Mnt. Everest, but it was much more than that. It wasa dangerous journey in which he never could have imagined. Krakauer describes the toll it put on the climbers to ascend Everest, and what exactly lays ahead for future climbers.

"As I began my descent I was extremely anxious, but my concern had little to do with the weather: a check of the gauge on my oxygen tank had revealed that it was almost empty. I needed to get down, fast. The uppermost shank of Everest's Southeast Ridge is a slender, heavily corniced fin of rock and windscourned snow that snakes for a quarter mile between the summit and a subcordinate pinnacle known as the South Summit. Negotiating the serrated ridge presents no great technical hurdles, but the route is dreadfully exposed. After leaving the summit, fifteen minutes of cautious shuffling over a 7,000-foot abyss brought me to the notorious Hillary Step, a pronounced notch in the ridge that demands some technical maneuvering. As I clipped into a fixed rope and prepared to rappel over the lip, I was greeted with an alarming sight." 
Krakauer, worried about the oxygen supply, does not stay at thetop long enough to string up banners or flags or pose for pictures. He turns to descend, passing some members of Fischer's expedition along the way. Krakauer notices some thin clouds, but does not recognize them as thunderheads. At Hillary Step he encounters a traffic jam and must wait for the other climbers to ascend. Krakauer asks Andy Harris to turn down his oxygen so as to preserve it until he can get another one,but Harris mistakenly opens the valve even farther and after ten minutes,Krakauer is out of oxygen.

\section{d) The storm force the climber after they summit the Everest}

In this story it is safe to say that the biggest conflict is man vs. nature. Jon Krakauer was originally sent up there to report commercialism on Mnt.Everest, but it was much more than that. It was a dangerous journey in whichhe never could have imagined. Krakauer describes the toll it put on the climbers to ascend Everest, and what exactly lays ahead for future climbers.

"Beidleman reaches the summit just after Krakauer leaves, at approximately $1: 25 \mathrm{pm}$. Boukreev and Harris are already there. Klev Schoening reaches the top twenty minutes later. By 2:00 pm, there is still no sign of Fischer or any of his clients, and Beidleman begins to worry about how late it is. Since 2:00 $\mathrm{pm}$ is the turn aroundtime, Fischer and Hall and the rest of the clients presumably should have turned back by then. Beidleman doesn't have a radio so he cannot contact Hall or Fischer. At 2:10 pm, Sandy Pittman appears with Lopsang and a couple other climbers. Hall, Mike and Yasuko Namba, the Japanese woman, summated at approximately the same time. Hall thought Doug Hansen and Fischer were just behind him,but they aren't-Fischer does not reach the top until $3: 40 \mathrm{pm}$ and Hansen not until 4:00 pm.”

\section{e) The storm caused some climbers die}

Beck Weathers says this to his teammates in Chapter 20 about how he was able to pick himself up, half frozen and left for dead, out ofthe snow. With this quote, Weathers emerges as an unlikely hero. He isloyal and steadfast in his promises, but the feat of strength and spirit hepulls off in this chapter is incredible. This episode exemplifies the consistent theme of solitude versus teamwork. Weathers is abandoned on the mountain, and a rescue group finds him, but thinks he is beyond saving. At that point, it seemed his fate was in the hands of his teammates, who let him down. Miraculously, Weathers regains consciousness and single-handedly finds and gets himself to Camp Four. Once he is there, his teammates try and warm him up, but again they leave him, thinking he cannot live through the night. Again, Beck defies the odds alone. Beck is the only climber who relies on his team members but survives despite their failure.

The climbing sherpas located Fischer and Gau on 11 May, but Fischer's condition had deteriorated so much that they were only able to give palliative care before rescuing Gau. Boukreev made a subsequent rescue attempt but found Fischer's frozen body at around 19:00. Like Weathers, Gau was evacuated by helicopter.

\section{Moral Value}

Moral values are happened by moral behavior in our life. Moral values as faced from a situation where man needs a movement and to behave in their habit, their relation with their God, in their culture and in their social life where he lived. According to Hurlock moral behavior means behavior in conformity with the moral code of social group. Moral development has both an intellectual and impulsive aspect.

Moral values can be used as moral education. In this research, the writer has found moral values in the novel Into Thin Air that are suggested for moral education. They are followings:

\section{a) Solitude and Self-Reliance}

The control over theexpedition and the actions and decisions of the climbers loosens more and moreuntil everyone, to some extent, is responsible for himself or herself. Climbing mountain is learning about self-responsibility. If you die in the mountain, thereis no remorse, guilt or sadness and announces simply that death does not change anything.

\section{b) Drive and Overdrive}

Drive is a necessary characteristic, but if left unchecked often results in poor decision-making and even death during expeditions.

\section{c) Perseverance}

The same perseverance that drives climbers to achieve amazing feats can lead them to keep plunging forward even when the odds have become insurmountable.

\section{d) Ambition}

The same ambition that leads these men to do great things ultimately hinders them when an unexpected disaster strikes. And their ambition killed themselves.

e) Mortality 
Some meet their ends suddenly; some keep fighting until they simply can't fight anymore; and some willingly sacrifice their lives in order to give others a fighting chance.

\section{CONCLUSION}

Based on the result of both findings and discussions, the research can be drawn as the followings;

\section{1) The major characters in the novel}

Jon Krakauer, Rob Hall, Andy Harris, Sandy Pittman and Beck Weathers are the main character in the story because they have contributed much in story.

\section{2) Physical conflicts}

These elements are related each other to make up a story. This is the step how the conflict rise up from the beginning to the end of story :

a) They missed the schedule

b) There is no oxygen and ropes in Hillary Step

c) The climbers get mountain sickness

d) The storm force the climber after they summit the Everest

e) The storm caused some climbers die

Ego is the main problem in mountain climbing. Ego to reach the highest peak in the world would invite people to come. They underestimate the schedule to summit, only few minutes after they celebrate their expeditions, a storm hits thesummit. Eight climbers killed and several others were stranded by a rogue storm. Jon Krakauer who submissive with the schedule, he safe. He catches only the tail end of storm before he successfully reaches the refuse of Camp Four.

\section{3) Moral Values}

This novel taught the reader about solitude and self- reliance during the expeditions, drive and overdrive herself or himself to prevail over the any conditions, being a perseverance climber and do not too ambition because ambition can killed and bring us to mortality.

\section{REFERENCES}

https://journal.stibaiec-jakarta/ojs/index.php/jell

Abrams, M.H. 1999. A Glossary of Literary Terms.United States: Heinle\&Heinle Thomson Learning.Seventh Edition.

Arikunto, S. 2000. Manajemen Penelitian. Jakarta: Rineka Cipta

Aziez, F. dan Hasim. A. 2010. Menganalisis Fiksi "Sebuah Pengantar". Bogor: Ghalia Indonesia (Anggota IKAPI).

Buzan, B. 2003. Security: A New Framework for Analysis. Boulder. CO: Lynne Rienner Publisher.

Bennet, A. and Royle, N. 2004. An Introduction to Literature, Criticismand Theory. New York: Pearson Longman.

Chapman, H. n.d. Handling the Exposition of a Story. Retrieved September 29,2016, from http://www.novel-writinghelp.com/exposition-of-a-story.html

Dietsch, B.M. 2003. Reasoning and Writing Well. New York: McGraw Hill.

Diyanni, R. 2001. Literature Reading, Fiction, Poetry, and Drama. Newyork:McGrawHill International Edition.

Hall, C. S. 1959. Pengantar ke Dalam Ilmu Jiwa Sigmund Freud. Jakarta: Pustaka Sarjana P.T. Pembangunan Jakarta.

Hasani, A. 2005. Ikhwal Menulis. Serang: Universitas Sultan Ageng Tirtayasa. Press.

Hornby, A.S. 2000. Oxford Advance Learner's Dictionary. Oxford: OxfordUniversity Press.

Hurlock, E. B. 1985. Child Development. New York: McGraw-Hill BookCompany.

J.B. Gordon, K. K. 1999. FICTION The Element of The Short Story. UnitedStates: McGrawHill Company.

Judith, A. S. 2006. Responding to Literature: Stories, Poems, Plays andEssays. New York: McGraw Hill.

Kennedy, X. J. 1983. Literature: An Introduction to Fiction, Poetry, and Drama (Third Edition). Boston: Little, Brown and Company. 


\section{Chandra Ivan and Agita Violy}

Physical Conflict Analysis in the Novel "Into Thin Air" by Jon Krakauer

Klarer, M. 2004. An Introduction to Literary Studies. London and New York: Routladge Taylor \& Francis Group, Second Edition.
Kothari, C.R. 2004. Research Methodology (Methods \& Techniques). New Delhi:New Age Publisher 